\title{
Wild-type p53 mediates positive regulation of gene expression through a specific DNA sequence element
}

\author{
Gerard P. Zambetti, ${ }^{1}$ Jill Bargonetti, ${ }^{2}$ Kristen Walker, $^{1}$ Carol Prives, ${ }^{2}$ and Arnold J. Levine ${ }^{1,3}$ \\ ${ }^{1}$ Department of Molecular Biology, Princeton University, Princeton, New Jersey 08544 USA; ${ }^{2}$ Department of Biological \\ Sciences, Columbia University, New York, New York 10027 USA
}

\begin{abstract}
It has been reported recently that the wild-type p53 gene product can positively regulate the expression of a test gene adjacent to the enhancer-promoter elements of the murine muscle-specific creatine kinase (MCK) gene. This discussion reports the identification of a wild-type p53 protein-specific DNA-binding element located within the p53-responsive region of the MCK enhancer-promoter element. This p53

protein/DNA-binding element has been defined by DNase I footprint analysis, which identified a 50-bp region. This 50-bp sequence was sufficient to confer wild-type p53 responsiveness on a heterologous minimal promoter. The mutant forms of 553 protein are much less capable of stimulating this DNA element. This study has identified the first example of a naturally occurring wild-type p53-specific DNA-binding element that is able to mediate positive regulation of a test gene. The results suggest a biological function in gene regulation for the wild-type p53 protein that is lost or altered in the mutant p53 proteins.
\end{abstract}

[Key Words: Wild-type p53 protein; DNA-binding element; enhancer]

Received March 23, 1992; revised version accepted April 22, 1992.

The wild-type p53 gene and gene product appear to regulate cell proliferation negatively. This gene is able to inhibit the transformation of primary cells in culture by other oncogenes (Eliyahu et al. 1989; Finlay et al. 1989) and can suppress the ability of transformed cells to form tumors in animals (Chen et al. 1990). When the wildtype p53 gene is returned to transformed cells and expressed in excess, the gene product blocks cell proliferation (Baker et al. 1990; Diller et al. 1990; Mercer et al. 1990 ), and these cells accumulate in the late $G_{1}$ phase of the cell cycle (Michalovitz et al. 1990; Martinez et al. 1991). The DNA tumor viruses and natural forms of cancers have used two distinct mechanisms to overcome the negative regulation of cell division by the p53 protein. The DNA tumor viruses encode oncogene products that can bind to wild-type p53 and presumably inactivate the functions that negatively regulate cell division (Lane and Crawford 1979; Linzer and Levine 1979; Sarnow et al. 1982; Werness et al. 1990). In naturally occurring cancers, the p53 gene frequently sustains mutations producing missense or faulty p53 proteins with distinct properties (Hinds et al. 1990; Hollstein et al. 1991; Levine et al. 1991). Most commonly, one p53 allele in a cancer cell is found in the mutant form, whereas the second allele is lost by deletion or a reduction to homozygosity (Baker et al. 1989; Nigro et al. 1989; Takahashi et al. 1989; Levine et al. 1991). Indeed, presently, it appears that mutations

${ }^{3}$ Corresponding author. at the p53 locus are the most common genetic alteration observed in human cancers (Hollstein et al. 1991; Levine et al. 1991).

As a result, it is important to understand the function of the p53 gene products. The p53 protein resembles a transcriptional trans-activator protein based on its primary amino acid sequence (Pennica et al. 1984; Soussi et al. 1987). It has an amino-terminal acid domain (1-75 amino acid residues) and a carboxy-terminal basic domain (Pennica et al. 1984). The wild-type protein binds to DNA and can recognize and protect specific DNA sequences from digestion with DNase I (Lane and Gannon 1983; Steinmeyer and Deppert 1988; Bargonetti et al. 1991; Kern et al. 1991a,b|. A gene fusion of the acidic amino-terminal domain of p53 or the entire p53 protein with the DNA-binding domain of Gal4 will promote the expression of a test gene regulated by the Gal4 DNAbinding domain in yeast (Fields and Jang 1990) or in mammalian cells in culture (Fields and Jang 1990; Raycroft et al. 1990). Whereas wild-type p53-Gal4 fusion proteins promote the expression of such test genes, mutant forms of p53 protein fail to trans-activate these reporter genes at the Gal4-binding site (Raycroft et al. 1990, 1991).

Recently, Weintraub and his collaborators (1991) have demonstrated that a murine creatine phosphokinase gene and its enhancer-promoter elements could be regulated positively by the addition of the wild-type, but not the mutant form, of the p53 gene and protein. It 
remained unclear whether this was a direct effect of p53 on the enhancer or promoter elements or an indirect effect of the wild-type form of $\mathrm{p} 53$ on the cellular physiology or growth state. This was in contrast to the majority of reports where the wild-type p53 gene and product appear to negatively regulate cell growth and most enhancer-promoter elements (Ginsberg et al. 1991; Santhanam et al. 1991). It remains unclear how the $\mathrm{p} 53$ protein might function in these types of experiments.

To address this question more directly, the DNA element that was responsive to wild-type $\mathrm{p} 53$ protein in the creatine phosphokinase gene was mapped and identified by nucleotide sequence analysis. Using DNase I footprint analysis with this DNA and wild- type p53 proteins from murine or human sources, a 50-bp element was identified by these protection experiments. When this 50-bp element was placed $5^{\prime}$ to a minimal promoter, it conferred on the promoter the wild-type p53 protein-dependent expression of a test gene. The mutant forms of p53 protein had a much reduced ability to stimulate this DNA sequence motif.

This study demonstrates that the wild-type p53 protein can function directly to mediate positive regulation of gene expression in a DNA sequence-specific manner. This is the first characterization of a natural wild-type p53 DNA-binding element that is associated with a biological function.

\section{Results}

Wild-type p53 trans-activates muscle creatine kinase

The trans-activation of the muscle creatine kinase (MCK) gene by the wild-type p53 protein was studied previously in cell lines that contain either endogenous wild-type or mutant p53 proteins, or both (Weintraub et al. 1991). The presence of an endogenous p53 protein in a cell could complicate the interpretation of these results owing to the interactions between mutant and wild-type p53 proteins. To eliminate this possibility, the transactivation of the MCK gene by wild-type $\mathrm{p} 53$ protein was carried out in the Saos- 2 human osteogenic sarcoma cell line (Masuda et al. 1987) and the (10)1 spontaneously arising, immortalized mouse embryo fibroblast cell line (Harvey and Levine 1991), both of which have no endogenous p53 protein expressed. These two cell lines are devoid of endogenous p53 protein because of major deletions in the $5^{\prime}$ region of the p53 gene. As a positive control to confirm the initial observation made by Weintraub and co-workers, the African green monkey CV-1 cell line (Jensen et al. 1964), which presumably expresses wild-type p53, was also used in these p53 trans-activation studies.

The cell lines were transfected by use of a calcium phosphate precipitation with the MCKCAT reporter gene alone or in combination with wild-type p53 DNA (p11-4) or mutant p53 (pSVKH215) genes. Forty-eight hours after transfection, the cells were harvested and analyzed for chloramphenicolacetyl transferase (CAT) expression. As observed in Figure 1, the MCKCAT gene
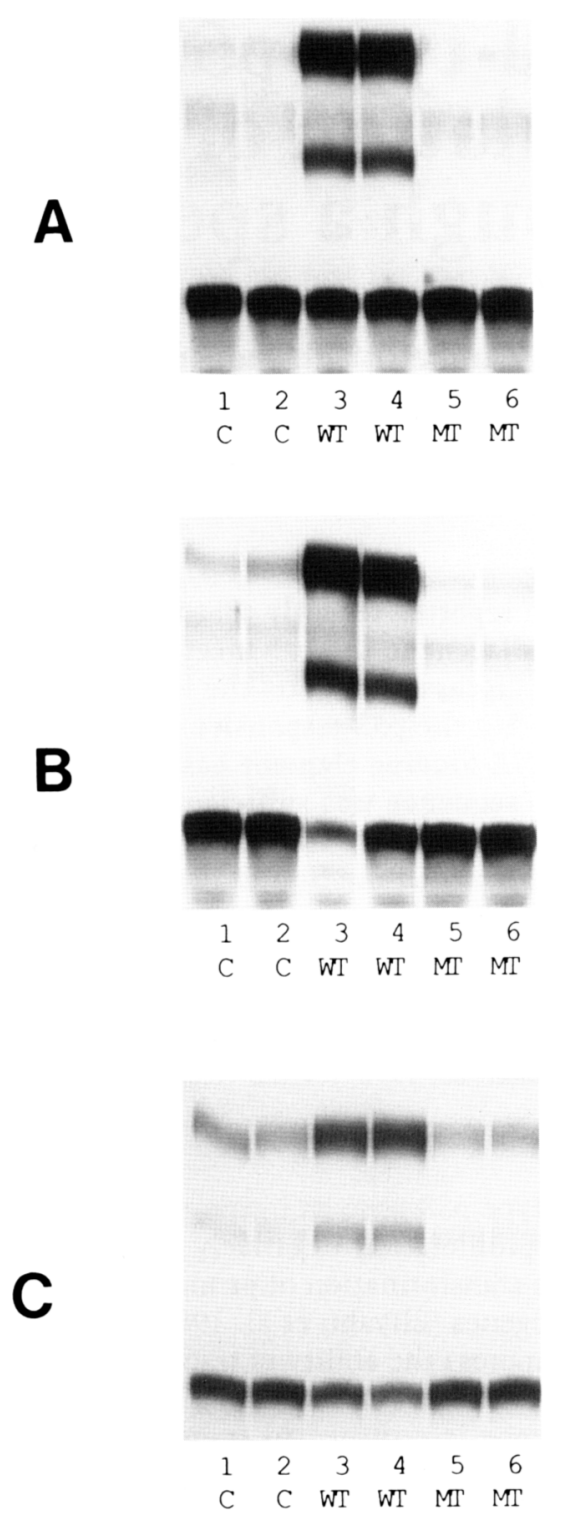

Figure 1. Wild-type p53 trans-activates the MCK promoter. Cells were transfected in duplicate with pMCKCAT plasmid DNA alone $\{\mathrm{C}=$ control, MCKCAT only; lanes 1,2), pMCKCAT DNA and murine wild-type p53 cDNA plasmid DNA (p11-4) (WT = wild-type p53, MCKCAT + p1 1-4; lanes 3,4), or pMCKCAT DNA and murine mutant p53 DNA (pSVKH215) (MT = mutant p53, MCKCAT + pSVKH215; lanes 5,6) and assayed for CAT activity as described in Materials and methods. (A) Saos-2 human osteogenic sarcoma cell line; $(B) \mathrm{CV}-1$ African green monkey kidney cell line; $(C)(10) 1$ spontaneously arising immortalized murine fibroblast cell line.

alone is poorly expressed when transfected into either Saos-2 (Fig. 1A, lanes 1,2) or CV-1 cells (Fig. 1B, lanes $1,2)$. When MCKCAT is cotransfected with wild-type p53 (lanes 3,4), however, the level of CAT activity is induced a minimum of sevenfold over MCKCAT alone (lanes 1,2) or MCKCAT and mutant p53 (lanes 5,6) based on densitometric analysis of the autoradiographs. Trans- 
activation of MCKCAT in this assay is specific for wildtype p53, as cotransfection with mutant p53 has no effect on CAT levels (lanes 5,6). Although the basal levels of CAT activity are much greater in the (10)1 cell line (Fig. 1C, lanes 1,2), it is clear that wild-type p53 and not mutant p53 can trans-activate the MCK promoter /cf. lanes 3 and 4 with lanes 5 and 6, respectively) approximately twofold above this background level. Occasionally, the mutant p53 protein actually decreased the levels of CAT activity (Fig. 1B); however, this was not a reproducible observation.

Trans-activation of MCKCAT by wild-type p53 is also evident when studied in a transformed rat embryo fibroblast (A-15 cell line) that expresses a temperature-sensitive murine mutant p53 protein (Michalovitz et al. 1990; Martinez et al. 1991). The temperature-sensitive p53 gene contains a point mutation that results in an alanine-to-valine substitution at amino acid residue 135 . At high temperature $\left(39^{\circ} \mathrm{C}\right), \sim 80 \%$ of the protein is in the mutant conformation and $20 \%$ is in the wild-type conformation, as determined by reactivity with conformational-dependent monoclonal antibodies. In contrast, at low temperature $\left(32.5^{\circ} \mathrm{C}\right), 80 \%$ of p53 is in the wild-type conformation. To examine trans-activation of the MCK promoter in these cells, A-1 cells were transfected with MCKCAT in a calcium phosphate precipitate at $37^{\circ} \mathrm{C}$ as usual and, $24 \mathrm{hr}$ later, were transferred either to $39^{\circ} \mathrm{C}$ or $32.5^{\circ} \mathrm{C}$. The cells were incubated at the appropriate temperature for an additional $24 \mathrm{hr}$ and analyzed for CAT activity as described in Materials and methods. As a control for temperature effects, transformed rat embryo fibroblasts (T101-4 cell line) expressing a mutant $\mathrm{p} 53$ protein not conditional for temperature were also studied in parallel. As seen in Figure 2, MCKCAT activity was significantly greater (three- to fourfold stimulation based on densitometric analysis) in A-15 cells at low temperature (lanes 1,2 ) when the majority of the $\mathrm{p} 53$ protein is in a wild-type conformation, as compared with high temperature (lanes 3,4 ) when the p53 protein is in a mutant conformation. The levels of CAT activity were relatively equal at both low and high temperature in the T101-4 cell line (lanes 5-8), indicating that the differences observed in CAT activity in the A-1 cell line were related to the conformation of the $\mathrm{p} 53$ protein and not to the temperature of incubation per se. The results presented in Figures 1 and 2 demonstrate that the induction of MCK promoter activity in these assays is dependent on coexpression of wild-type p53, and this effect can be observed in a wide variety of cell lines with or without endogenous p53 proteins.

\section{A p53-responsive element is located in the distal promoter region of the muscle-specific creatine kinase gene}

It was shown previously by deletion analysis of the MCK promoter that a p53-responsive element may be located within the distal region of the promoter (Weintraub et al. 1991). Deletion of nucleotides -3300 to -2800 , with respect to the transcription start site, abolishes trans-

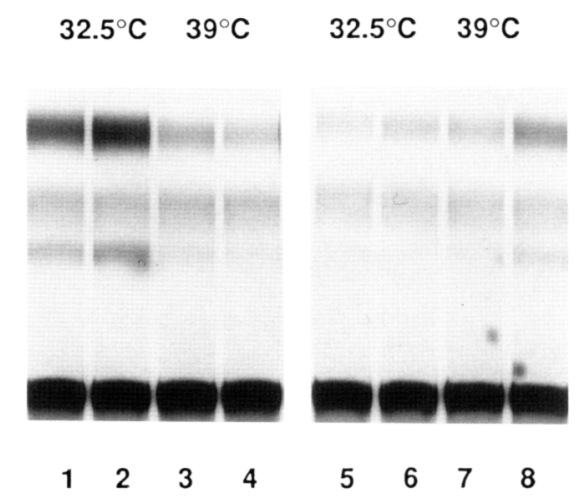

Figure 2. Conditional trans-activation of the MCK promoter by a temperature-sensitive mutant $\mathrm{p} 53$ protein. Transformed rat embryo fibroblast cell cultures were transfected in duplicate with pMCKCAT plasmid DNA at $37^{\circ} \mathrm{C}$ in a calcium phosphate precipitate for $18 \mathrm{hr}$ and incubated at either $32.5^{\circ} \mathrm{C}$ or $39^{\circ} \mathrm{C}$ for $48 \mathrm{hr}$. Cells were harvested and analyzed for CAT activity as described in Materials and methods. A1-5-transformed rat embryo fibroblasts (left) express a temperature-sensitive mutant murine p53 (alanine to valine substitution at amino acid 135) where the protein is in a wild-type conformation at $32.5^{\circ} \mathrm{C}$ and in a mutant conformation at $37-39^{\circ} \mathrm{C}$. T101-4-transformed rat embryo fibroblasts (right) express a mutant murine p53 (HindIII linker insertion at codon for amino acid 215), which is not conditional for temperature. Lanes 1 and 2 (A1-5) and lanes 5 and 6 (T101-4) represent MCKCAT activity at $32.5^{\circ} \mathrm{C}$. Lanes 3 and 4 (Al-5) and lanes 7 and $8(\mathrm{~T} 101-4)$ represent MCKCAT activity at $39^{\circ} \mathrm{C}$.

activation of MCKCAT by wild-type p53. It was unclear whether a p53-responsive element was self-contained within this region or whether cooperating elements lying downstream from this distal region were also required. To sort out these possibilities, the distal $500 \mathrm{bp}$ spanning nucleotides -3300 to -2800 were subcloned into heterologous promoter elements to determine whether these sequences were sufficient to confer wildtype p53 responsiveness. The 500-bp Sall fragment from MCK was cloned upstream from the herpes simplex virus (HSV) thymidine kinase minimal promoter-CAT reporter gene (pBLCAT2; Luckow and Shutz 1987) resulting in the construction of pMTC32. Transfection of the parent vector pBLCAT2 into Saos- 2 cells results in the synthesis of moderate levels of CAT activity [Fig. 3A, lanes 1,2 (C)]. Cotransfection of Saos-2 cells with pBLCAT2 and the wild-type p53 plasmid dramatically reduces CAT expression [lanes 3,4 (WT)] and apparently is a consequence of a general inhibitory effect of wildtype p53 on the transcriptional activity of a variety of promoters (Ginsberg et al. 1991; Santhanam et al. 1991). In contrast, mutant p53 plasmids do not have a suppressive effect on the expression of CAT activity by pBLCAT2 in Saos-2 cells [lanes 5,6 (MT)]. Incorporation of the 500-bp Sall fragment from MCK into the thymidine kinase minimal promoter, however, relieved the suppression of CAT expression by wild-type p53. Transfection of Saos-2 cells with pMTC32 alone or in combination with wild-type or mutant p53 resulted in high 

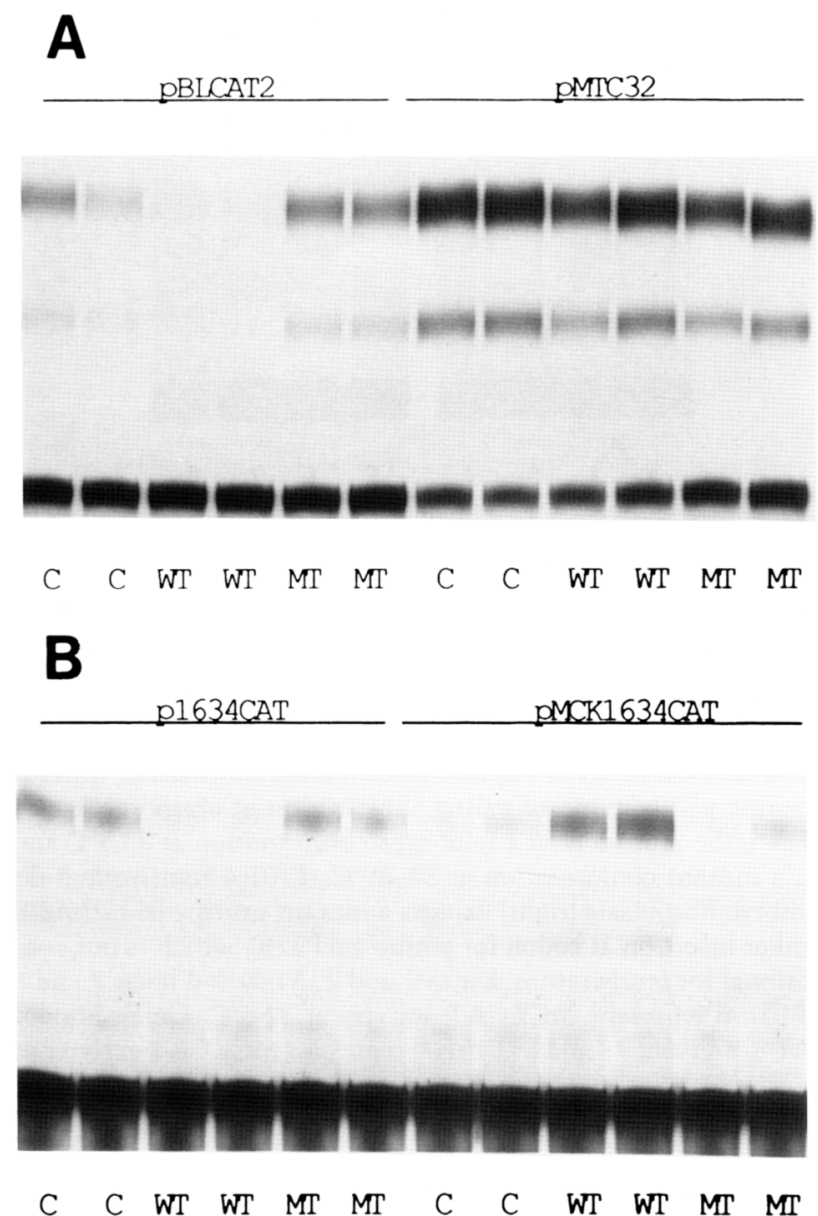

Figure 3. Mapping the wild-type p53-responsive element to a distal region in the MCK promoter. The 500-bp Sall fragment from the MCK gene (corresponding to nucleotides -2800 to -3300 ) was subcloned upstream from the HSV promoter-CAT gene in pBLCAT2 and upstream from the Ad MLTATA box/ TdTint-CAT gene in p1634, resulting in the construction of pMTC32 and pMCK1634CAT, respectively. Saos-2 cells were transfected in duplicate with these reporter genes alone $\{C\rangle$ or cotransfected with the reporter gene and either wild-type p53 (WT) or mutant p53 (MT). Cells were harvested and analyzed for CAT activity as described in Materials and methods. $|A|$ Saos- 2 cells transfected with the thymidine kinase promoter-based reporter constructs; $(B)$ Saos- 2 cells transfected with the Ad MLP/ TdTint-based reporter constructs.

levels of CAT activity [lanes 7-12 (C, WT, and MT, respectively)]. These results are consistent with the possibility that a p53-responsive element is contained within -3300 and -2800 nucleotides of the MCK promoter and that this element is sufficient to override the negative effect of wild-type p53 on the thymidine kinase promoter. This experiment, however, does not permit any conclusions about positive regulation by p53 protein above the promoter element itself. The increase in the levels of CAT activity in Saos-2 cells with no p53 observed when pMTC32CAT is used compared with pBLCAT2 is undoubtedly the result of the action of other transcription factors on the extra $500 \mathrm{bp}$ found in the former plasmid.

To address this question, the MCK-SalI fragment containing the p53-responsive element was subcloned into p1634CAT DNA, which encodes a minimal hybrid promoter consisting of the adenovirus major late TATA (Ad MLTATA) sequences and the terminal deoxynucleotidyltransferase transcription initiation site (Ad MLP/TdTint) fused to a CAT reporter gene (Shi et al. 1991), resulting in the construction of pMCK1634CAT. Transfection of Saos- 2 cells with the original vector p1634CAT alone (Fig. 3B, lanes 1,2) or with p1634CAT and mutant p53 (lanes 5,6) yielded low levels of CAT activity. Wildtype p53 also had a suppressive effect $\mid>60 \%$ reduction in CAT expression compared with p1634CAT alone or p1634CAT and mutant p53 based on densitometric analysis) on this minimal hybrid promoter (lanes 3,4 ), as was observed for the HSV thymidine kinase promoter. Incorporation of the 500-bp SalI fragment from MCK into the Ad MLP/TdTint hybrid minimal promoter clearly confers wild-type $\mathrm{p} 53$ responsiveness. Transfection of Saos- 2 cells with either pMCK1634CAT (Fig. 3B, lanes 7,8) or pMCK1634CAT and mutant p53 (lanes 11,12 ) resulted in low levels of CAT activity, whereas cotransfection of Saos-2 cells with pMCK1634CAT and wild-type p53 (lanes 9,10$)$ resulted in a minimum of a threefold induction of CAT expression based on densitometric analysis. The extent of induction of CAT activity in pMCK1634CAT and wild-type p53 cotransfected cells is comparable to the trans-activation of the full muscle creatine kinase promoter ( $3300 \mathrm{bp}$ ) by wild-type p53, as shown in Figure 1. These results define a region between -3300 and $-2800 \mathrm{bp}$ in the MCK promoter that is sufficient to confer wild-type $\mathrm{p} 53$ responsiveness to a heterologous promoter.

\section{p53 protein binds the MCK promoter}

The induction of MCK promoter activity by wild-type p53 may be a direct effect of p53 protein binding to a regulatory element within the promoter. Alternatively, wild-type p53 may influence the physiology of the cell in such a way that the MCK promoter may become transcriptionally active. To better understand the regulation of MCK promoter activity by wild-type p53, the 500-bp SalI fragment of MCK, which is p53 responsive, was sequenced as described in Materials and methods. As shown in Figure 4, an 8-bp direct repeat (CTGCCTCT) is located between nucleotides -3156 and -3149 and displays a high degree of homology to a p53 DNA-binding element identified by Vogelstein and co-workers (Kerns et al. 1991b). Vogelstein and co-workers have also reported a second sequence that is capable of binding wildtype p53. It also contains two TGCCT repeats that are spaced by $12 \mathrm{bp}$, which suggests that there may be flexibility in the size and sequence of the spacer region between repeated elements for effective p53 binding (Kerns et al. 1991b). Furthermore, an SP1-like GC-rich region adjacent to the TGCCT repeats at nucleotides -3165 to -3156 in the MCK p53-responsive region shares se- 
$-3300$

ATTCCCCATC CTGGTCTATA GAGAGAGITC CAGAACAGCC AGGGCTACAG ATAAACCCAT

CTGGAAAAAC AAAGTTGAAT GACCCAAGAG GGGTTCTCAG AGGGTGGCGT GTGCTCCCIG GCAAGCCTAT GACATGGCCG GGGCCTGCCT CTCTCTGCCT CTGACCCICA GIGGCTCCCA TGAACTCCTT GCCCAATGGC ATCTTTTTCC TGCGCICCTT GGGTTATTCC AGTCTCCCCT CAGCATTCCT TCCTCAGGGC CTCGCTCTTC TCTCTGCTCC CTCCTTGCAC AGCTGGCTCT GTCCACCTCA GATGTCACAG TGCTCTCTCA GAGGAGGAAG GCACCATGTA CCCTCIGTTT CCCAGGTAAG GGTTCAATTT TTAAAAATGG TTTTTGTTTG TTTGTTTGT"T TGTTTGTTTG TTTGTTICAA GACAGGGCIC CTCIGIGTAG TCCTAACTGT CAAGAAACTC CCTCGTAGAC $-2813$ CAGGTOGA

Figure 4. Nucleotide sequence of the wild-type p53-responsive domain of the MCK promoter. The 500-bp Sall fragment from the MCK promoter was sequenced by the Sanger dideoxynucleotide method. Nucleotide number -3300 has been estimated from the restriction endonuclease map of the MCK gene (Jaynes et al. 1988); therefore, nucleotide -2813 represents the approximate distance from the MCK TATA element. The p53 DNAbinding region in the MCK promoter, which was identified by DNase I footprint analysis (Figs. 5 and 6), is underlined.

quence homology to the p53 DNA-binding sites identified in the SV40 virus origin of replication by Prives and co-workers (Bargonetti et al. 1991).

The possibility that the MCK promoter may bind wild-type p53 selectively was first addressed by use of an assay to detect p53 binding to DNA with radiolabeled DNA and antibodies directed against the 553 protein to coimmunoprecipitate specific DNA fragments bound to p53 proteins (McKay 1981). When this was done it was found that immunopurified wild-type p53 protein was selectively bound to a DNA fragment in the p53-responsive enhancer element (Fig. 4) and not to the other DNA fragments in this mixture (data not shown).

The region of interaction between wild-type p53 protein and the p53-responsive region of the MCK promoter was next defined by DNase I footprint analysis (Fig. 5). Both murine and human wild-type p53 protein purified from baculovirus-infected insect cells protected a 50-bp region of the MCK promoter corresponding to the GCrich box (region 1), the TGCCT repeats (regions 2 and 3), and several additional downstream nucleotides (region 4) spanning nucleotides -3182 to -3133 (Figs. 5 and 6). Included within this region are two DNase I hypersensitive sites located $3^{\prime}$ to each TGCCT motif. These results demonstrate a p53 DNA-binding region in the p53responsive element of the $\mathrm{MCK}$ promoter. The results further indicate that there may be more than one p53binding element where region 1 is related to the p53. binding site located in the SV40 virus origin of replication (Bargonetti et al. 1991) and regions 2 and 3 share homology to sequences in the DNA fragments identified previously by Vogelstein's group (Kerns et al. 1991b). It is of interest to note that although both the human and mouse $\mathrm{p} 53$ proteins bind to this sequence, only the murine $\mathrm{p} 53$ has been reported to activate a test gene with this sequence (Weintraub et al. 1991).

\section{The p53 DNA-binding site in the MCK promoter is a p53-responsive element}

DNA-binding studies using the immunoprecipitation assay and DNase I footprint analysis defined a 50-bp region within the MCK promoter that interacts with the wildtype p53 protein in vitro (Figs. 5 and 6). To determine whether this p53-binding site is functionally competent

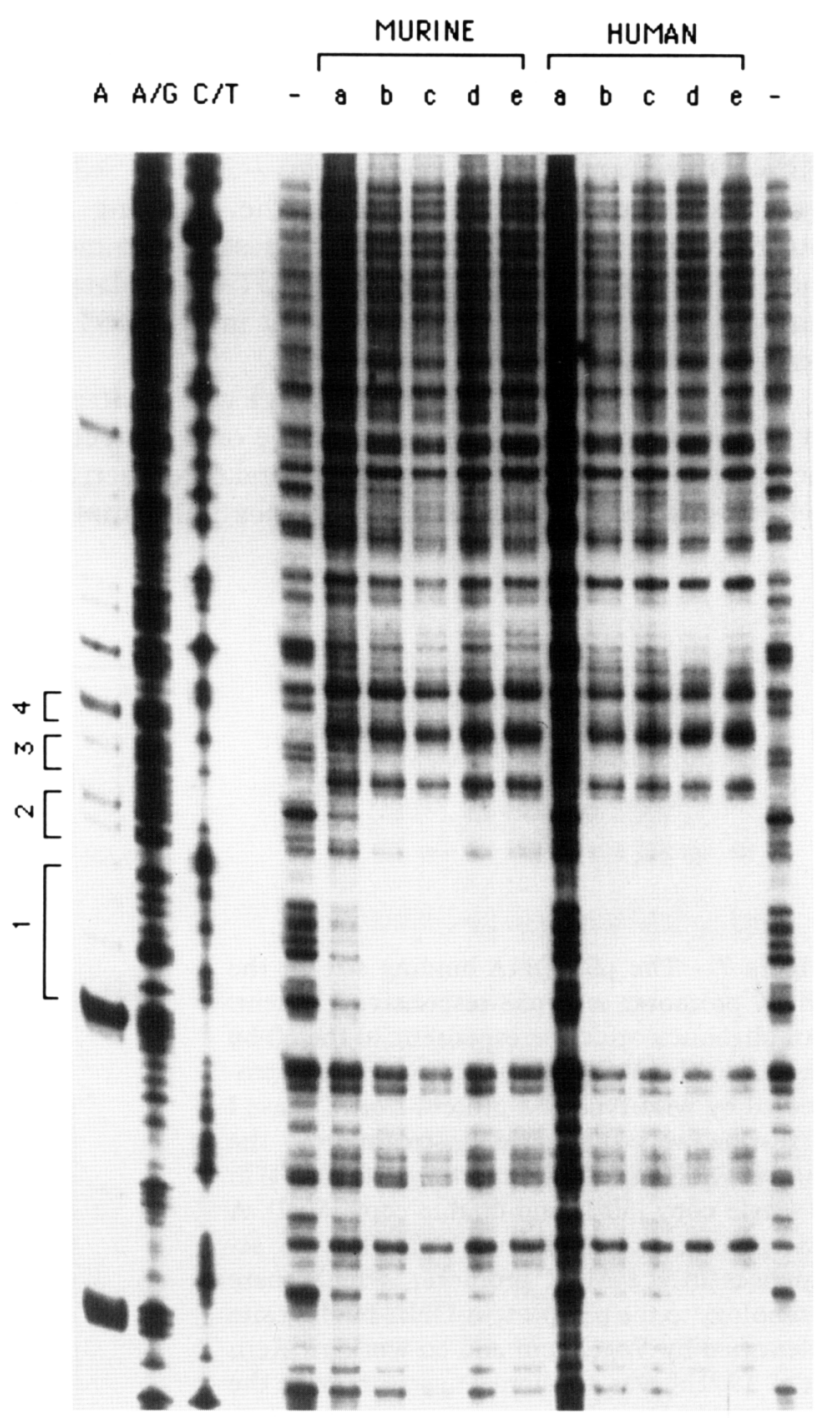

Figure 5. Wild-type p53 protein binds to specific DNA sequences in the p53-responsive region of the MCK promoter. Murine and human wild-type p53 protein binding to the MCK promoter was examined by DNase I footprint analysis as described in Materials and methods. $1-1$ Lanes contained no protein; lanes $a$ to $e$ contained $15,30,45,60$, and $75 \mathrm{ng}$, respectively. Discrete regions protected by $\mathrm{p} 53$ protein are indicated by brackets at (left). 


\section{$1+\frac{3}{-1}-4$ TGGCAAGCCTATGACATGGCCGGGGCCTGCCTCTCTCTGCCTCTGACCCT}

Figure 6. Nucleotide sequence of the p53-specific DNA-binding region of the MCK promoter. The p53-specific binding region of the MCK promoter was identified by DNase I footprint analysis as described in Materials and methods (see Fig. 5). Region 1 is similar in nucleotide sequence to the p53-binding site in the SV40 DNA origin of replication (Bargonetti et al. 1991); regions 2 and 3 share sequence homology to the p53-binding sites identified previously by Vogelstein and co-workers (Kern et al. 1991b).

to confer p53-dependent gene expression, the 50-bp element was inserted as a single copy and in double copy upstream of the Ad MLP/TdTint minimal promoterCAT reporter gene (p1634CAT). A 25-bp fragment (a half-site) containing the two TGCCT repeats (flanked by 5 bp at the $5^{\prime}$ and $3^{\prime}$ ends; nucleotides -3160 to -3135 ) was also cloned into p1634CAT. The resulting constructs were tested for $\mathrm{p} 53$ responsiveness by cotransfection of Saos-2 cells (Fig. 7) and BALB/c3T3 cells (data not shown) with and without wild-type or mutant p53 in a transient assay.

As observed in Figure 7, the MCKCAT gene by itself or with the mutant p53 plasmid had little or no detectable activity (cf. lanes 1 and 2 with lanes 5 and 6 , respectively) whereas the wild-type p53 plasmid (lanes 3,4 ) stimulated high levels of CAT activity (minimum of fivefold induction over MCKCAT alone or MCKCAT and mutant p53). The promoter element by itself (p1634; lanes 7,8$)$ or with wild-type p53 plasmid (lanes 9,10) expressed low levels of CAT activity. In this experiment the mutant p53 plasmid did provide a threefold higher level of CAT activity with the promoter element 1634CAT (lanes 11,12), but this was not a consistent finding. Similarly, the half-site containing the TGCCT repeated motif alone (lanes $13,14)$ was not significantly stimulated by the wild-type p53 plasmid (lanes 15,16 ) or by the mutant p53 plasmid (lanes 17,18 ). In contrast, the entire 50-bp motif that binds wild-type p53 protein in vitro was stimulated /a minimum of sixfold) by the wild-type p53 plasmid (lanes 21 and 22 for two copies of the 50-bp repeat; lanes 27 and 28 for one copy). The mutant p53 plasmid (lanes $23,24,29,30$ ) acted on these DNA sequences to provide an approximate twofold stimulation of CAT activity over the 50-bp elements alone (lanes 19,20,25,26; evident in longer exposures). Furthermore, the 50-bp element functions equally well in either orientation with respect to the TATA box and transcription start site, which is consistent with the possibility that this p53 DNA-binding site functions as an enhancer element (data not shown).

These results demonstrate clearly that the DNA sequence recognized by wild-type p53 protein can also confer on a minimal promoter element the ability to express a gene in a $\mathrm{p} 53$-dependent fashion. Wild-type $\mathrm{p} 53$ protein
Figure 7. The p53 DNA-binding site in the MCK promoter is a p53-responsive element. An oligonucleotide corresponding to the 50-bp region in the MCK promoter, which was protected by wild-type p53 protein from DNase I digestion, was subcloned upstream from the Ad MLP/TdTint-CAT reporter gene (p1634) in a single copy (50-1) and double copy (50-2). A 25-bp oligonucleotide encompassing the sequences in the MCK promoter, which share homology to the $\mathrm{p} 53$ protein-DNA-binding site identified by Vogelstein and co-workers (Kern et al. 1991b), was subcloned upstream from the Ad MLP/TdTint promoter in a single copy. The reporter constructs were transfected in duplicate into Saos- 2 cells either alone $(C)$ or with wild-type p53 (WT) or mutant p53 (MT) and subsequently analyzed for CAT activity as described in Materials and methods. (Top) A 16hr exposure; (bottom) a 3-hr exposure of Kodak XAR-5 X-ray film to the chromatographed CAT assay samples.
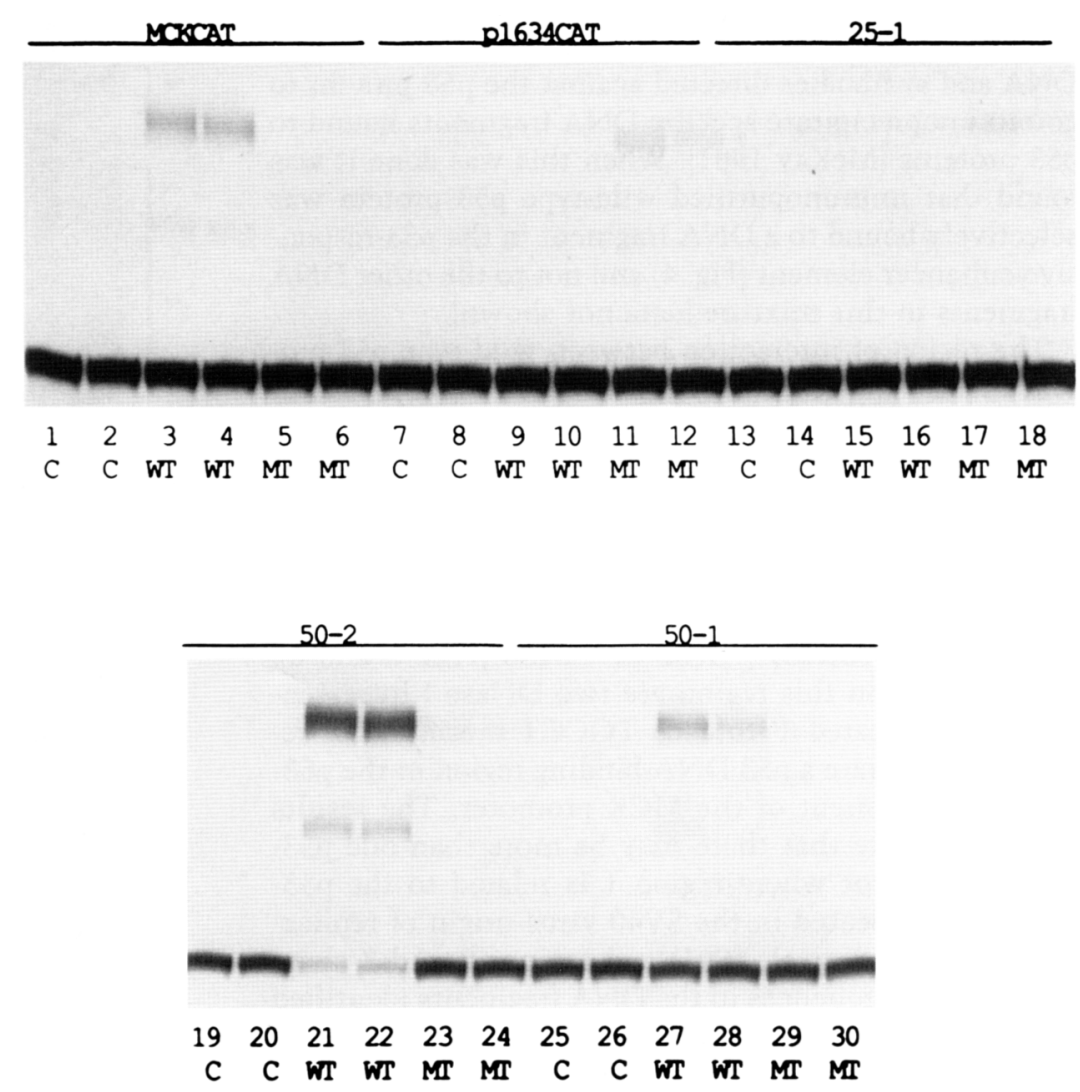
is more efficient at this than is mutant $\mathrm{p} 53$ protein. The p53 protein can mediate the positive regulation of a gene through a specific DNA sequence element.

\section{Discussion}

Several lines of evidence have suggested a possible function of the p53 wild-type protein as a transcriptional trans-activator of specific genes. First, the primary sequence of the protein resembles some transcription factors (Pennica et al. 1984). The first 75 amino acids, which are very acidic, can act in a fusion protein with the Gal4 DNA-binding domain to positively promote the expression of a test gene in yeast (Fields and Jang 1990) or in mammalian cells (Fields and Jang 1990; Raycroft et al. 1990). The carboxy-terminal domain of p53 protein is quite basic. The wild-type protein binds to DNA, whereas the mutant forms of the p53 protein bind less well or not at all to nonspecific DNA sequences (Steinmeyer and Deppert 1988; Kern et al. 1991a,b). Recently, the wild-type p53 proteins have been shown to bind to DNA in a sequence specific manner (Bargonetti et al. 1991; Kern et al. 1991b). In one study a sequence motif with a TGCCT $(\mathrm{N})_{5-12}$ TGCCT was detected as an important element for p53 recognition to DNA (Kern et al. 1991b). In a second study a GC-rich domain with SP1 sequence elements near the origin of SV40 DNA replication (near the 21-bp repeats of SV40 DNA) was identified as a specific DNA sequence recognized by the wild-type p53 protein (Bargonetti et al. 1991). These two nucleotide sequences do not have extensive homology or easily recognizable similarities.

Recently, Weintraub and co-workers have identified an enhancer-promoter element that regulates the muscle form of creatine phosphokinase gene, which was positively regulated by the expression of the wild-type p 53 gene, but not plasmids containing the mutant forms of p53 (Weintraub et al. 1991). In this study the p53-responsive element in this enhancer-promoter region was mapped to the location between -2800 and $-3300 \mathrm{nu}-$ cleotides $5^{\prime}$ to the transcriptional start site of this gene. The nucleotide sequence of this region of the enhancer was determined, and a direct binding of wild-type p53 protein from human and mouse identified a 50-bp region recognized by this protein. It was of some interest that this 50-bp region may be divided into two parts: a GCrich sequence element that resembles the SV40 21-bp repeat region and a TGCCT repeated element. It is possible that this naturally occurring element is a combination of the two DNA sequence motifs reported previously to bind the wild-type p53 protein (Bargonetti et al. 1991; Kern et al. 1991b). When an oligonucleotide was synthesized with this 50 -bp sequence, it conferred the ability to regulate positively a gene under the control of a minimal promoter in a wild-type p53 protein-specific fashion. Two copies of this 50-bp element were more responsive than one copy, and mutant forms of $\mathrm{p} 53$ were less capable of regulating this minimal promoter. Thus, the $\mathrm{p} 53$ protein appears to function by binding to specific
DNA sequences and positively regulating an adjacent gene.

When $\mathrm{T}$ antigen from SV40 is bound to p53, it fails to bind to specific DNA sequences (Bargonetti et al. 1991) and could inactivate p53 function in that fashion. Similarly, mutant forms of $\mathrm{p} 53$ bind less well to DNA, do not result in a clear footprint with DNase I cleavage, and stimulate this 50 -bp site in a much poorer fashion than the wild-type p53 proteins. It may only be coincidence, but it is worth pointing out that an SV40 large T-antigenbinding site (GAGGC) is encoded within regions 2 and 3 (Fig. 6) of the p53-responsive DNA-binding element in the MCK promoter. Such a close association or overlap of p53 and T-antigen-binding elements (seen in the SV40 21-bp region) could have biological meaning.

It is of some interest that the $\mathrm{p} 53$ protein binds to a TGCCT motif that is in the 25-bp element but that this sequence is not sufficient to confer p53-dependent positive regulation of the test gene. Clearly, DNA binding is therefore not the equivalent of regulating gene expression. Rather, both nucleotide-sequence motifs (Figs. 5 and 6, regions $1-4$ ), which can bind p53 protein separately, are required to observe expression of the test gene. The simplest hypothesis is that the p53-responsive element located -2800 to -3300 bp from the transcriptional start site is acting as an enhancer element and p53 binding would be expected to promote transcription of this gene. Consistent with that hypothesis is the fact that the 50-bp MCK p53-responsive element functions in both orientations (G.P. Zambetti and A.J. Levine, data not shown) and that some p53 DNA-binding elements can act with a basal promoter to activate transcription in vitro in a wild-type p53 protein-dependent fashion /G. Farmer, J. Bargonetti, H. Zhu, P.N. Friedman, R. Prywes, and C. Prives, in press).

Thus, the results presented in this discussion are the first identification of a natural p53-specific binding element that is associated with a biological function. The wild-type $\mathrm{p} 53$ protein, but not mutant forms of this protein, may well regulate a set of genes in a positive fashion that prevent entry of cells into a proliferative cycle. The p53 mutations reduce DNA sequence recognition, and the oncogene products of the DNA tumor viruses prevent DNA binding (Lane and Crawford 1979; Linzer and Levine 1979; Sarnow et al. 1982) or destroy the p53 protein (Scheffner et al. 1990; Werness et al. 1990). In light of previous suggestions that the p53 protein binds to DNA recognition sites near putative origins of DNA replication (Bargonetti et al. 1991; Kern et al. 1991b), the wild-type p53 protein may even promote transcription across a DNA sequence that could result in the initiation of DNA replication. Further studies will be required to sort out these alternatives.

\section{Materials and methods}

Cell culture and transfection

The human osteogenic sarcoma cell line Saos- 2 contains an extensive deletion in the coding region of the p53 gene and is 
devoid of endogenous p53 mRNA and protein (Masuda et al. 1987). CV-1 cells are an African green monkey kidney cell line (Jensen et al. 1964) that presumably synthesizes wild-type p53 protein. The spontaneously arising immortalized murine BALB/c embryo fibroblast (10) 1 cell line (Harvey and Levine 1991) contains large deletions in both p53 alleles and, consequently, is negative for $\mathrm{p} 53$ protein. The A- 1 cell line is derived from rat embryo fibroblasts transformed by a temperature-sensitive mutant murine p53 gene (alanine to valine at amino acid 135) and an activated ras gene (Finlay et al. 1988). At $32.5^{\circ} \mathrm{C}$ the exogenous p53 protein is predominantly in the wild-type conformation and the cells are growth arrested in the $G_{1}$ phase of the cell cycle (Michalovitz et al. 1990; Martinez et al. 1991). At high temperature $\left(39^{\circ} \mathrm{C}\right)$ the murine p53 protein is primarily in the mutant conformation and the cells grow exponentially. T101-4 cells are rat embryo fibroblasts transformed with a mutant murine $\mathrm{p} 53$ gene containing a linker insertion mutation at amino acid 215 (KH215), which is not affected by temperature, and an activated ras gene (Finlay et al. 1988). All cell lines were maintained as monolayer cultures in Dulbecco's minimal essential medium (DMEM) containing $10 \%$ heat-inactivated fetal bovine serum, $2 \mathrm{~mm}$ glutamine, penicillin-G $(100 \mathrm{U} / \mathrm{ml})$, and streptomycin $(100 \mu \mathrm{g} / \mathrm{ml})$ (completed medium) at the appropriate temperature in a humidified $5 \% \mathrm{CO}_{2} / 95 \%$ air atmosphere.

The cells were plated at $\sim 20 \%$ confluency in a $10-\mathrm{cm}^{2}$ tissue culture dish (Corning, Chicago, IL) in $12 \mathrm{ml}$ of completed medium and incubated at $37^{\circ} \mathrm{C}$ for $18-20 \mathrm{hr}$. The cells were refed with $15 \mathrm{ml}$ of completed medium, cultured for $4 \mathrm{hr}$, and transfected with DNA (10 $\mu \mathrm{g} /$ construct and adjusted to $20 \mu \mathrm{g}$ total with sheared salmon sperm DNA) that was prepared in a calcium phosphate precipitate as described previously by Graham and van der Eb (1973). The transfected cells were incubated at $37^{\circ} \mathrm{C}$ for $\sim 18 \mathrm{hr}$, washed twice with prewarmed phosphate-buffered saline (PBS), and refed with $12 \mathrm{ml}$ of completed medium. The cells were incubated at the appropriate temperature $\left(32.5^{\circ} \mathrm{C}, 37^{\circ} \mathrm{C}\right.$, or $\left.39^{\circ} \mathrm{C}\right)$ for an additional $48 \mathrm{hr}$. The transfected cells were washed with PBS and scraped from the plates in $1 \mathrm{ml}$ of STE $[150 \mathrm{~mm} \mathrm{NaCl}, 10 \mathrm{mM}$ Tris- $\mathrm{HCl}(\mathrm{pH} 7.4)$, and $1 \mathrm{~mm}$ EDTA]. The cells were centrifuged at $12,000 \mathrm{~g}$ for $20 \mathrm{sec}$, resuspended in $200 \mu \mathrm{l}$ of $0.25 \mathrm{M}$ Tris- $\mathrm{HCl}$ ( $\mathrm{pH} 8.0$ ), and lysed by three cycles of freeze-thawing, alternating between a dry ice/ethanol bath and $37^{\circ} \mathrm{C}$ water bath (5 min at each temperature). Cellular debris was removed by centrifugation for $5 \mathrm{~min}$ at $12,000 \mathrm{~g}$, and the protein concentration of each sample was determined by the Bradford assay.

\section{Plasmids}

The MCKCAT gene is encoded by p3300MCKCAT, which contains $3300 \mathrm{bp}$ of the murine MCK upstream control region fused to the coding region of the bacterial CAT gene (Jaynes et al. 1988). pBLCAT2 consists of the HSV thymidine kinase promoter $(-105$ to +51$)$ fused to the CAT reporter gene (Luckow and Shutz 1987). pl634 (referred to as PTI in Shi et al. 1991) is a chimeric minimal promoter CAT reporter gene transcriptionally regulated by the Ad MLTATA and TdT gene initiator motif. pl1-4 encodes a murine wild-type p53 cDNA under the transcriptional regulation of the SV40 promoter, and pSVKH 215 consists of an SV40 promoter controlling the expression of a murine mutant p53 cDNA that contains an insertion of a HindIII linker (12-mer) in the KpnI site at amino acid 215 (Tan et al. 1986). pMTC32 was constructed by inserting the 500-bp SalI fragment from MCKCAT, which was blunt-ended by the large Klenow fragment of DNA polymerase I into the BamHI-Klenow site of pBLCAT2. pMCK1634CAT was constructed by inserting the 500-bp SalI-Klenow fragment from MCKCAT into the EcoRV site of p1634 DNA. A synthetic double-stranded oligonucleotide consisting of the following sequences, 5'-GGG CCT GCC TCT CTC TGC CTC TGA C- $3^{\prime}$, was cloned into the EcoRV site of p1634 DNA to construct p25-1 (single-copy insert; oriented in forward direction with respect to TATA box). A synthetic double-stranded oligonucleotide consisting of the following sequences, 5'-TGG CAA GCC TAT GAC ATG GCC GGG GCC TGC CTC TCT CTG CCT CTG ACC CT-3', was cloned into the EcoRV site of pl634 DNA, resulting in the construction of p50-1 (single copy; oriented in forward direction) and p50-2 (two copies; oriented in forward direction). The 500bp SalI fragment of MCKCAT was sequenced in both orientations by the Sequenase method (U.S. Biochemical Corporation; Cleveland, $\mathrm{OH})$.

\section{CAT assays}

Equal quantities of protein were assayed for CAT activity /Gorman et al. 1982) on the basis of protein concentration as determined by the Bradford method (Bio-Rad Laboratories, Richmond, CA). Extracts were incubated with $0.1 \mu \mathrm{Ci}$ of ${ }^{14} \mathrm{C}$-labeled chloramphenicol and $4 \mathrm{~mm}$ acetyl coenzyme $\mathrm{A}$ in $0.5 \mathrm{~m}$ Tris$\mathrm{HCl}(\mathrm{pH} 8.0)$ at $37^{\circ} \mathrm{C}$ for $1.5 \mathrm{hr}$. The reactions were extracted with $1 \mathrm{ml}$ of ethyl acetate and dried under vacuum at room temperature for several hours. The samples were resuspended in $25 \mu \mathrm{l}$ of ethyl acetate and loaded onto silica gel-preadsorbent/channeled thin layer chromatography plates (Baker Si250PA19C; purchased from VWR Scientific) and chromatographed in $95 \%$ chloroform, $5 \%$ methanol. The plates were airdried and subjected to autoradiography and densitometric analysis.

\section{Protein-DNA complex immunoprecipitation assay}

Sequence-specific DNA-binding activity of murine wild-type p53 was examined according to a modified McKay assay (1981) as described by Kern et al. (1991b). The 500-bp SalI fragment from the MCK promoter was digested with StyI and BanI restriction endonucleases resulting in the formation of three fragments of the following sizes: 217,160 , and $123 \mathrm{bp}$. The DNA fragments were subsequently radiolabeled by filling in the $5^{\prime}$ overhangs with $\left[\alpha^{-32} \mathrm{P}\right] \mathrm{dCTP}$ and Klenow enzyme as described previously (Maniatis et al. 1982). Murine wild-type p53 was purified from Spodoptera frugiperda insect cells ( $\mathrm{Sf} 27$ cells) infected with vEV55p53 recombinant baculovirus (O'Reilly and Miller 1988), as described previously (Wang et al. 1989). Wildtype p53 protein $(5 \mu \mathrm{l} ; 25 \mathrm{ng}$ of protein $/ \mu l)$ was incubated with $4 \times 10^{5}$ to $6 \times 10^{5} \mathrm{cpm}{ }^{32}$ P-labeled DNA $(1 \mu \mathrm{l}), 800 \mathrm{ng}$ of purified monoclonal antibodies (in $8 \mu \mathrm{l}$ of binding buffer), and $95 \mu 1$ of binding buffer $[20 \mathrm{~mm}$ Tris- $\mathrm{HCl}(\mathrm{pH} 7.2), 100 \mathrm{~mm} \mathrm{NaCl}, 10 \%$ glycerol, $1 \% \mathrm{NP}-40,5 \mathrm{~mm}$ EDTA] at $4^{\circ} \mathrm{C}$ for $30 \mathrm{~min}$. Simultaneously, protein A-Sepharose (1.5 mg) (Sigma) was incubated with $12.5 \mu \mathrm{g}$ of poly[d(I-C)]/poly[d(I-C)] (Pharmacia) in $25 \mu \mathrm{l}$ of binding buffer on ice for $30 \mathrm{~min}$. The protein A-Sepharose solution was added to the DNA-binding reaction and incubated while rotating at $4^{\circ} \mathrm{C}$ for $30 \mathrm{~min}$. The immunoprecipitates were washed twice with $500 \mu \mathrm{l}$ of binding buffer and digested in 160 $\mu \mathrm{l}$ of $10 \mathrm{~mm}$ Tris- $\mathrm{HCl}$ (pH 9.0), $1 \mathrm{~mm}$ EDTA, $20 \mu \mathrm{l}$ of $10 \%$ SDS, and $5 \mathrm{mg} / \mathrm{ml}$ of proteinase $\mathrm{K}$ (Sigma) at $50^{\circ} \mathrm{C}$ for $1 \mathrm{hr}$. The samples were diluted with $100 \mu \mathrm{l}$ of $10 \mathrm{~mm}$ Tris- $\mathrm{HCl}(\mathrm{pH} 9.0)$ and $1 \mathrm{~mm}$ EDTA and extracted with $300 \mu \mathrm{l}$ of phenol-chloroform and $300 \mu \mathrm{l}$ of chloroform. The DNA was ethanol-precipitated, resuspended in $10 \mu \mathrm{l}$ of $2 \%$ SDS loading buffer, and analyzed by electrophoresis through a $3 \%$ Nusieve-agarose gel (FMC BioProducts, Rockland, ME) and autoradiography. 


\section{DNase I footprinting}

The labeled MCK fragment was prepared by digesting pSCMCK-3 (G.P. Zambetti and A.J. Levine, unpubl.) with XhoI and labeling with the large fragment of DNA polymerase I and $\left[{ }^{32} \mathrm{P}\right] \mathrm{dNTPs}$. The mixture was then digested with $P_{s t} \mathrm{I}$, and the 500-bp end-labeled fragment was gel purified. The labeled strand corresponds to the bottom strand of the sequence shown. Reaction mixtures $(50 \mu \mathrm{l})$ containing $40 \mathrm{~mm}$ creatine phosphate (di-Tris salt, pH 7.7), $4 \mathrm{~mm}$ ATP, $7 \mathrm{~mm} \mathrm{MgCl}_{2}, 0.2 \mathrm{mg} / \mathrm{ml}$ of bovine serum albumin, $0.5 \mathrm{~mm}$ DTT, $10 \mathrm{ng}$ of the plasmid pATI53 (Twigg and Sheratt 1980), and 10-12 fmoles of ${ }^{32} \mathrm{P}$-labeled DNA fragment were preincubated for $5 \mathrm{~min}$ at $37^{\circ} \mathrm{C}$. Binding of the p53 protein to DNA /at protein concentrations indicated in Fig. 5/ was allowed to proceed for $15 \mathrm{~min}$ at $37^{\circ} \mathrm{C}$. The amount of DNase I required to produce an even pattern of partial cleavage products was pretested empirically; in general, $4-10 \mu \mathrm{l}$ of a freshly diluted solution of $0.5 \mu \mathrm{g} / \mathrm{ml}$ solution in 20 $\mathrm{mM} \mathrm{CaCl} 2$ was used. After digestion, $50 \mu \mathrm{l}$ of DNase stop solution $(2 \mathrm{M}$ ammonium acetate, $100 \mathrm{mM}$ EDTA, $0.2 \%$ SDS, 100 $\mu \mathrm{g} / \mathrm{ml}$ of sheared salmon sperm DNA) was added, and the DNA was extracted with phenol and ethanol precipitated. The DNA was then electrophoresed on a $6 \%$ denaturing polyacrylamide gel. This procedure is described in more detail in Bargonetti et al. (1991).

\section{Acknowledgments}

This research was supported by U.S. Public Health Service grant P01-CA41086-03 from the National Cancer Institute. G. Zambetti is supported by a Damon Runyon-Walter Winchell Cancer Research Fund Fellowship (DRG-1096). J.B. is supported by a Damon Runyon-Walter Winchell Cancer Research Fund Fellowship (DRG-1133). We sincerely thank Dr. Harold Weintraub for his suggestions and critical review of this manuscript. We also thank Diane Harvey for the immortalized murine cell lines and Cathy Finlay, Robin Quartin, Jamil Momand, Joseph Bayle, and David Olson for their helpful discussions and suggestions.

The publication costs of this article were defrayed in part by payment of page charges. This article must therefore be hereby marked "advertisement" in accordance with 18 USC section 1734 solely to indicate this fact.

\section{Note added in proof}

Sequence data described in this paper have been submitted to the EMBL/GenBank data libraries.

\section{References}

Baker, S.J., E.R. Fearon, J.M. Nigro, S.R. Hamilton, A.C. Preisinger, J.M. Jessup, P. van Tuinen, D.H. Ledbetter, D.F. Barker, Y. Nakamura, R. White, and B. Vogelstein. 1989. Chromosome 17 deletions and p53 gene mutations in colorectal carcinomas. Science 244: 217-221.

Baker, S.J., S. Markowitz, E.R. Fearon, J.K.V. Willson, and B. Vogelstein. 1990. Suppression of human colorectal carcinoma cell growth by wild-type p53. Science 249: 912-915.

Bargonetti, J., P.N. Friedman, S.E. Kern, B. Vogelstein, and C. Prives. 1991. Wild-type but not mutant p53 immunopurified proteins bind to sequences adjacent to the SV40 origin of replication. Cell 65: 1083-1091.

Chen, P.-L., Y. Chen, R. Bookstein, and W.-H. Lee. 1990. Genetic mechanisms of tumor suppression by the human p53 gene. Science 250: 1576-1580.
Diller, L., J. Kassel, C.E. Nelson, M.A. Gryka, G. Litwak, M. Gebhardt, B. Bressac, M. Ozturk, S.J. Baker, B. Vogelstein, and S.H. Friend. 1990. p53 functions as a cell cycle control protein in osteosarcomas. Mol. Cell. Biol. 10: 5775-5781.

Eliyahu, D., D. Michalovitz, S. Eliyahu, O. Pinhasi-Kimhi, and M. Oren. 1989. Wild-type p53 can inhibit oncogene-mediated focus formation. Proc. Natl. Acad. Sci. 86 8763-8767.

Farmer, G.E., J. Bargonetti, H. Zhu, P.N. Friedman, R. Prywes, and C. Prives. 1992. Wild-type p53 activates transcription in vitro. Nature (in press).

Fields, S. and S.K. Jang. 1990. Presence of a potent transcription activating sequence in the p53 protein. Science 249: 10461049.

Finlay, C.A., P.W. Hinds, T.-H. Tan, D. Eliyahu, M. Oren, and A.J. Levine. 1988. Activating mutations for transformation by p 53 produce a gene product that forms an hsc70-p 53 complex with an altered half-life. Mol. Cell. Biol. 8: 531-539.

Finlay, C., P. Hinds, and A.J. Levine. 1989. The p53 proto-oncogene can act as a suppressor of transformation. Cell 57: 1083-1093.

Ginsberg, D., F. Mechta, M. Yaniv, and M. Oren. 1991. Wildtype p53 can down-modulate the activity of various promoters. Proc. Natl. Acad. Sci. 88: 9979-9983.

Gorman, C.M., L.F. Moffat, and B.H. Howard. 1982. Recombinant genomes which express chloramphenicol acetyltransferase in mammalian cells. Mol. Cell. Biol. 2: 1044-1051.

Graham, F.L. and A.J. van der Eb. 1973. A new technique for the assay of infectivity of human adenovirus 5 DNA. Virology 52: 456-467.

Harvey, D. and A.J. Levine. 1991. p53 alteration is a common event in the spontaneous immortalization of primary BALB/c murine embryo fibroblasts. Genes \& Dev. 5: 23752385.

Hinds, P.W., C.A. Finlay, R.S. Quartain, S.J. Baker, E.R. Fearon, B. Vogelstein, and A.J. Levine 1990. Mutant p53 cDNAs from human colorectal carcinomas can cooperate with Ras in transformation of primary rat cells. Cell Growth Differ. 1: $571-580$.

Hollstein, M., D. Sidransky, B. Vogelstein, and C.C. Harris. 1991. p53 mutations in human cancers. Science 253: 49-53.

Jaynes, J.B., J.E. Johnson, J.N. Buskin, C.L. Gartside, and S.D. Hauschka. 1988. The muscle creatine kinase gene is regulated by multiple upstream elements, including a musclespecific enhancer. Mol. Cell. Biol. 8: 62-70.

Jensen, F.C., A.J. Girardi, R.V. Gilden, and H. Koprowski. 1964. Infection of human and simian tissue cultures with rous sarcoma virus. Proc. Natl. Acad. Sci. 53: 53-59.

Kern, S.E., K.W. Kinzler, S.J. Baker, J.M. Nigro, V. Rotter, A.J. Levine, P. Friedman, C. Prives, and B. Vogelstein. 1991a. Mutant $\mathrm{p} 53$ proteins bind DNA abnormally in vitro. Oncogene 6: 131-136.

Kern, S.E., K.W. Kinzler, A. Bruskin, D. Jarosz, P. Friedman, C. Prives, and B. Vogelstein. 1991b. Identification of p53 as a sequence specific DNA-binding protein. Science 252: 17081711.

Lane, D.P. and L.V. Crawford. 1979. T antigen is bound to host protein in SV40-transformed cells. Nature 278: 261-263.

Lane, D.P. and J. Gannon. 1983. Cellular proteins involved in SV40 transformation. Cell. Biol. Int. Rep. 7: 513-514.

Levine, A.J., J. Momand, and C.A. Finlay. 1991. The p53 tumor suppressor gene. Nature 351: 453-456.

Linzer, D.I.H. and A.J. Levine. 1979. Characteriztion of a 54K dalton cellular SV40 tumor antigen present in SV40-transformed cells and uninfected embryonal cells. Cell 17: 43-52.

Luckow, B. and G. Shutz. 1987. CAT constructions with multiple unique restriction sites for the functional analysis of 
eukaryotic promoters and regulatory elements. Nucl. Acids Res. 15: 5490.

Maniatis, T., E.F. Fritsch, and J. Sambrook. 1982. Molecular cloning: A laboratory manual. Cold Spring Harbor Laboratory, Cold Spring Harbor, New York.

Martinez, J., I. Georgoff, J. Martinez, and A.J. Levine. 1991. Cellular localization and cell cycle regulation by a temperaturesensitive p53 protein. Genes \& Dev. 5: 151-159.

Masuda, H., C. Miller, H.P. Koeffler, H. Battifora, and M.J. Cline. 1987. Rearrangements of the p53 gene in human osteogenic sarcomas. Proc. Natl. Acad. Sci. 84: 7716-7719.

McKay, R.D.G. 1981. Binding of a simian virus $40 \mathrm{~T}$ antigenrelated protein to DNA. J. Mol. Biol. 145: 471-488.

Mercer, W.E., M.T. Shields, M. Amin, G.J. Sauve, E. Appella, J.W. Romano, and S.J. Ullrich. 1990. Negative growth regulation in a glioblastoma tumor cell line that conditionally expresses human wild-type p53. Proc. Natl. Acad. Sci. 87: 6166-6170.

Michalovitz, D., O. Halevy, and M. Oren. 1990. Conditional inhibition of transformation and of cell proliferation by a temperature-sensitive mutant p53. Cell 62: 671-680.

Nigro, J.M., S.J. Baker, A.C. Preisinger, J.M. Jessup, R. Hostetter, K. Cleary, S.H. Bigner, N. Davidson, S. Baylin, P. Devilee, T. Glover, F.S. Collins, A. Weston, R. Modali, C.C. Harris, and B. Vogelstein. 1989. Mutations in the p53 gene occur in diverse human tumour types. Nature 342: 705-708.

O'Reilly, D.R. and L.K. Miller. 1988. Expression and complex formation of simian virus 40 large $T$ antigen and mouse p53 in insect cells. J. Virol. 62: 3109-3119.

Pennica, D., D.V. Goeddel, J.S. Hayflick, N.C. Reich, C.W. Anderson, and A.J. Levine. 1984. The amino acid sequence of murine p53 determined from a cDNA clone. Virology 134: 477-482.

Raycroft, L., H. Wu, and G. Lozano. 1990. Transcriptional activation by wild-type but not transforming mutants of the p53 anti-oncogene. Science 249: 1049-1051.

Raycroft, L., J.R. Schmidt, K. Yoas, M. Hao, and G. Lozano. 1991. Analysis of p53 mutants for transcriptional activity. Mol. Cell. Biol. 11: 6067-6074.

Santhanam, U., A. Ray, and P.B. Sehgal. 1991. Repression of the interleukin 6 gene promoter by the $\mathrm{p} 53$ and the retinoblastoma susceptibility gene product. Proc. Natl. Acad. Sci. 88: 7605-7609.

Sarnow, P., Y.S. Ho, J. Williams, and A.J. Levine. 1982. Adenovirus E1b-58kd tumor antigen and SV40 tumor antigen are physically associated with the same $54 \mathrm{kd}$ cellular protein in transformed cells. Cell 28: 387-394.

Scheffner, M., B.A. Werness, J.M. Huibregtse, A.J. Levine, and P.M. Howley. 1990. The E6 oncoprotein encoded by human papilloma virus types 16 or 18 promotes the degradation of p53. Cell 63: 1129-1136.

Shi, Y., E. Seto, L.-S. Chang, and T. Shenk. 1991. Transcriptional repression by YY1, a human GL1-Kruppel-related protein, and relief of repression by adenovirus E1A protein. Cell 67: 377-388.

Soussi, T., C. Caron de Fromental, M. Mechali, P. May, and M. Kress. 1987. Cloning and characterization of a cDNA from Xenopus laevis coding for a protein homologous to human and murine p53. Oncogene 1: 71-78.

Steinmeyer, K. and W. Deppert. 1988. DNA binding properties of murine p53. Oncogene 3: 501-507.

Takahashi, T., M.M. Nau, I. Chiba, M.J. Birrer, R.K. Rosenberg, M. Vinocour, M. Levitt, H. Pass, A.F. Gazdar, and J.D. Minna. 1989. p53: A frequent target for genetic abnormalities in lung cancer. Science 246: 491-494.

Tan, F.-H., J. Wallis, and A.J. Levine. 1986. Identification of the p53 domain involved in formation of the simian virus 40 large T-antigen-p53 complex. I. Virol. 59: 574-583.

Twigg, A.J. and D. Sheratt. 1980. Trans-complementable copynumber mutants of ColE1. Nature 283: 216-218.

Wang, E.H., P.N. Friedman, and C. Prives. 1989. The murine p53 protein blocks replication of SV40 DNA in vitro by inhibiting the initiation functions of SV40 large $\mathrm{T}$ antigen. Cell 57: 379-392.

Weintraub, H., S. Hauschka, and S. Tapscott. 1991. The MCK enhancer contains a p53 responsive element. Proc. Natl. Acad. Sci. 88: 4570-4571.

Werness, B.A., A.J. Levine, and P.M. Howley. 1990. Association of human papillomavirus types 16 and 18 E6 proteins with p53. Science 248: 76-79. 


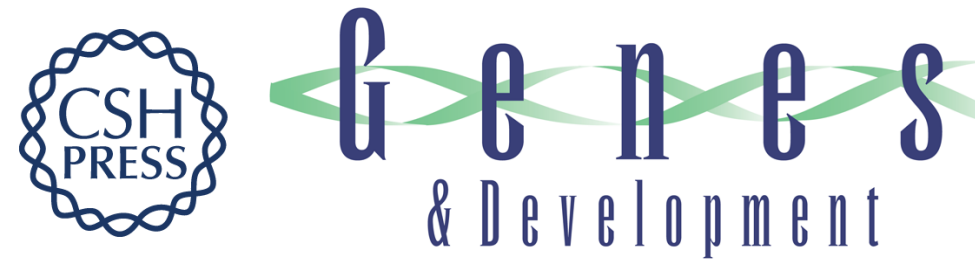

\section{Wild-type p53 mediates positive regulation of gene expression through a specific DNA sequence element.}

G P Zambetti, J Bargonetti, K Walker, et al.

Genes Dev. 1992, 6:

Access the most recent version at doi:10.1101/gad.6.7.1143

References This article cites 46 articles, 24 of which can be accessed free at: http://genesdev.cshlp.org/content/6/7/1143.full.html\#ref-list-1

License

Email Alerting Service right corner of the article or click here.

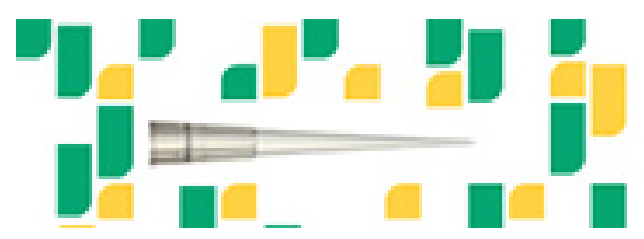

